\title{
Remote sounding of Greenland supraglacial melt lakes: implications for subglacial hydraulics
}

\author{
Jason E. BOX, ${ }^{1,2}$ Kathleen SKI ${ }^{1}$ \\ ${ }^{1}$ Department of Geography, The Ohio State University, 1036 Derby Hall, 154 North Oval Mall, Columbus, \\ Ohio 43210-1361, USA \\ E-mail: box.11@osu.edu \\ ${ }^{2}$ Byrd Polar Research Center, The Ohio State University, 1090 Carmack Road, Columbus, Ohio 43210-1002, USA
}

\begin{abstract}
A supraglacial lake-depth retrieval function is developed, based on the correspondence between moderate-resolution imaging spectroradiometer (MODIS) reflectance and water depth measured during raft surveys. Individual lake depth, area and volume statistics, including short-term temporal changes for Greenland's southwestern ablation region, were compiled for 2000-05. The maximum area of an individual lake was found to be $8.9 \mathrm{~km}^{2}$, the maximum volume $53.0 \times 10^{6} \mathrm{~m}^{3}$ and the maximum depth $12.2 \mathrm{~m}$, sampling over $0.0625 \mathrm{~km}^{2}$ pixel areas. The total lake volume reaches $>1 \mathbf{~ k m}^{3}$ in this region by July each year. The importance of melt lake reservoirs to Greenland ice-sheet flow may be a feedback between abrupt lake drainage events and ice dynamics. Lake-outburst volumes up to $31.5 \times 10^{6} \mathrm{~m}^{3} \mathrm{~d}^{-1}$ are capable of providing sufficient water via moulins to hydraulically pressurize the subglacial environment. Since the overburden pressure at the base of a flooded moulin is greater than that provided by ice, lake-outburst events seem capable of exerting sufficient upward force to lift the ice sheet locally, if water flow in the subglacial environment is constrained laterally. Considering a moulin with a $10 \mathrm{~m}^{2}$ cross-sectional area, basal pressurization can be maintained over lake-outburst episodes lasting hours to days.
\end{abstract}

\section{INTRODUCTION}

The Greenland ice sheet both indicates and reacts to climate. Recent warming has led to increases in summer melt extent (Abdalati and Steffen, 2001), melt duration and meltwater production/runoff (Box and others, 2006). Outlet glacier velocities have increased during this period of warming (Rignot and Kanagaratnam, 2006) in apparent response to enhanced water supply via a meltwater lubrication mechanism (Zwally and others, 2002; Vieli and others, 2004), signifying the important role of ice-sheet mass budget changes in global sea level and regional ocean circulation forcing.

Seasonal surface melting produces water that collects in surface undulation basins on the surface of the ice sheet (Thomsen and others, 1988; Echelmeyer and others, 1991; Lüthje and others, 2006). Thomsen and others (1988) observed: 'Many lakes exist on the ice surface, in many cases without any detectable surface outlets. They vary in size from only a few hundred meters in diameter up to about $1500 \mathrm{~m}$ and soundings in the lakes show mean water depths of $2-5 \mathrm{~m}$. The lakes tap periodically. From visits to empty lakes it can be seen that moulins often exist in the bottom of the lakes and from visits to the same locations in spring it is reasonable to assume that these moulins are filled with snow during winter, thus stopping the outlet. Lakes are then filled during summer until the moulins are reopened by a combination of pressure and melting. Similar observations were made in Spitsbergen (Liestøl and others, 1980).' The role of melt lakes in providing water to lubricate glacier flow in lake-outburst events has been hypothesized by Joughin and others (1996), Boon and Sharp (2003) and Parizek and Alley (2004), yet melt lake depth and volume statistics for the Greenland ice sheet, including their time variation, remain unresolved.
The relationship between surface melting, melt lakes and water discharge into englacial conduits (moulins) is also incompletely understood. Theoretical calculations by Weertman (1973), Van der Veen (1998) and Alley and others (2005) lead to the conclusion that a water-filled crevasse has unlimited capacity, acting under gravity, to force water to the bottom surface of a glacier. Water emanating from the glacier front, commonly laden with glacial silt, further indicates that water has been communicating with the bed some significant distance inland.

As water depth increases, scattering and absorption reduce the surface reflectance of solar radiation (Morassutti and LeDrew, 1996), amplifying melt (e.g. Curry and others, 1995; Perovich and others, 2002).

The present study exploits the water-depth-driven solar radiation extinction effect on spaceborne satellite-sensed surface reflectance, to develop an empirical parameterization to remotely sense melt lake depth and volume over the icesheet ablation region. Before applying depth parameterization, the surface is classified as flooded using thresholds in visible-band reflectance ratios and absolute reflectance, yielding lake area statistics. Downscaling methodologies are applied to coordinate the in situ depth measurements with satellite image data. Estimates of lake-dimension change are then made for southwestern ice-sheet lakes in 2000-05 cloud-free imagery. Uncertainty is discussed in conjunction with the development and application of the methods.

\section{DATA}

\section{MODIS data}

The moderate-resolution imaging spectroradiometer (MODIS) on the NASA Terra and Aqua satellites provides daily coverage of Greenland in optical and infrared 


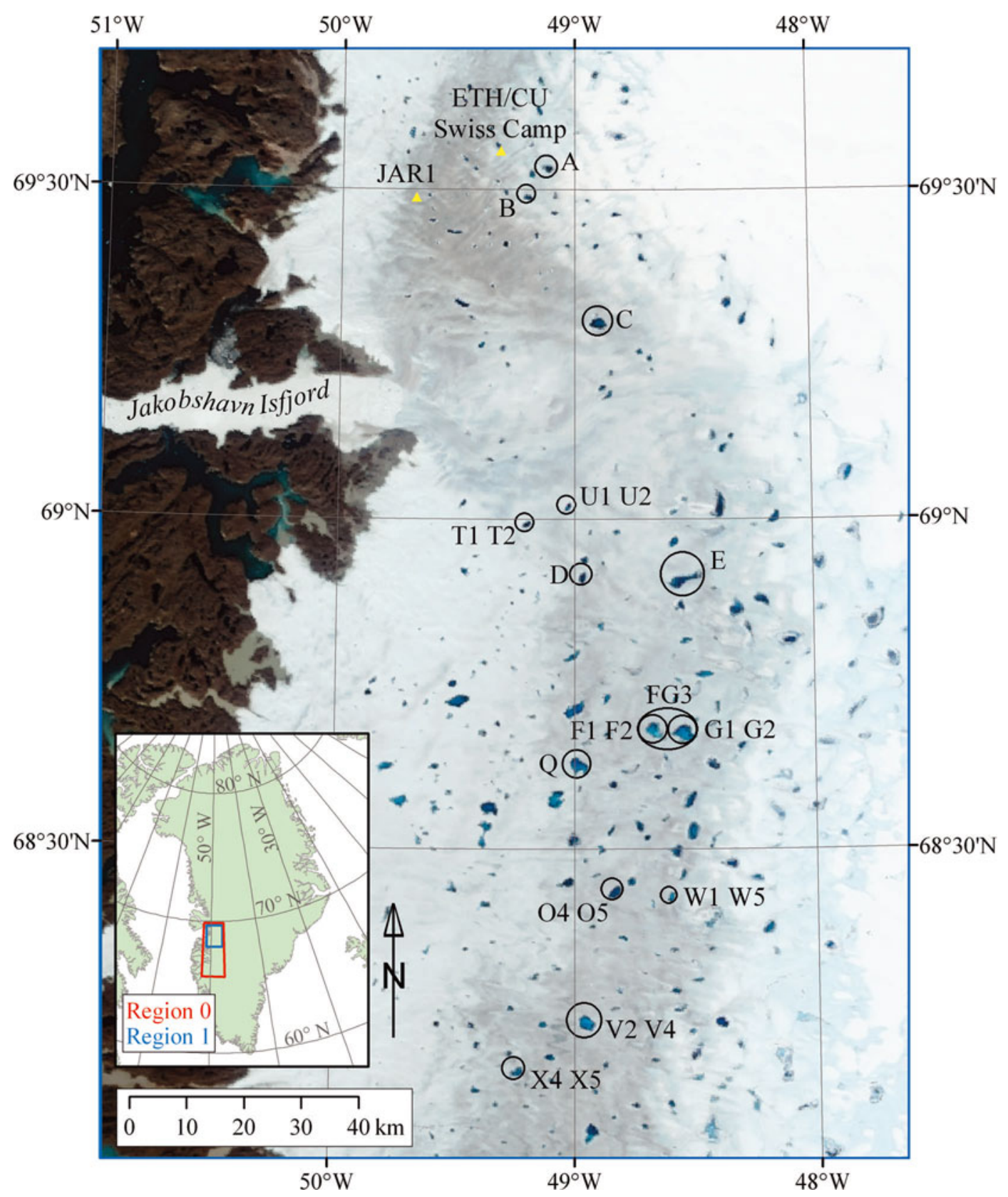

Fig. 1. MODIS $250 \mathrm{~m}$ true-color image composite, showing maximum melt lake extent (minimum reflectance) for 'region $1^{\prime}$, where a high concentration of lakes is found. The background image was acquired by MODIS, 26 August 20031540 UTC. Melt lakes investigated in this study are illustrated, including ground-surveyed lakes A and B, melt lakes with no obvious outburst events and lakes with annually recurring outbursts.

wavelength bands. MODIS data spanning the visible spectrum, i.e. band $1(0.62-0.67 \mu \mathrm{m}$, red), band $4(0.54-$ $0.57 \mu \mathrm{m}$, green) and band $3(0.46-0.48 \mu \mathrm{m}$, blue) are employed in this study. Band 1 has greater horizontal resolution $(250 \mathrm{~m})$ than bands 3 and $4(500 \mathrm{~m})$. For simplicity, bands 1, 4 and 3 are occasionally also referred to as red (R), green $(\mathrm{G})$ and blue (B), respectively.

MODIS data are advantageous for melt lake monitoring, given a $2330 \mathrm{~km}$ wide (cross-track) swath, capable of imaging the entire Greenland ice-sheet ablation zone daily. The wide swath in polar orbit also affords sub-daily repeat coverage. Relatively high-resolution Terra ASTER (Advanced Spaceborne Thermal Emission and Reflection Radiometer) or Landsat Enhanced Thematic Mapper (ETM) sensors have superior resolving power, making them desirable for melt lake investigations, but, with 60 and $185 \mathrm{~km}$ swath width, respectively, and a $4-16$ day repeat coverage, do not provide adequate temporal sampling to investigate lake-dimension change considering the observed timescales of development (Bryzgis and Box, 2005). Thus, this study relies upon MODIS image data. MODIS imagery spanning April-September 2000-05 (170 images, 28 per year) was gathered for use in this study.

The Terra (Earth Observing System) satellite overpasses Greenland with favorable solar illumination and near-nadir view, between 1410 and 1600 UTC, corresponding to a time of day within 2 hours after solar noon. For the relevant intervals of latitude $\left(67-70^{\circ} \mathrm{N}\right)$ and time of year (1 May to 31 August), the image data solar elevation angles are in the $25-44^{\circ}$ range. 
Lakes selected for investigation in this study are indicated on a maximum lake extent (2000-05) composite image (Fig. 1). The 16 August 20051445 UTC MODIS Terra imagery was selected to compare with ground-survey data to develop the depth-reflectance parameterizations. The lakes were obscured by clouds on 14 and 15 August 2005 when the surveys were undertaken.

\section{In situ data}

In situ depth surveys for lakes A and B (see Fig. 1) were made on 14 and 15 August 2005, respectively, using a $10 \mathrm{ft}(3 \mathrm{~m})$ inflatable raft propelled either by oars or by 5 h.p. outboard motor. Depth data were obtained using a Garmin 'Fish Finder 100' depth sounder with readings spoken into a microcassette recorder at waypoints recorded by a handheld GPS (global positioning system). Depth measurement precision was $0.1 \mathrm{~m}$, with accuracy matching that precision, according to measurement validation using a boat oar. Measurement position uncertainty is approximately $20 \mathrm{~m}$, as GPS data contained no differential correction. Table 1 provides additional depth-survey information.

Automatic weather station (AWS) data from the Greenland Climate Network (Steffen and others, 1996; Steffen and Box, 2001) are referred to in terms of the Jakobshavn ablation region (JAR). The AWS JAR1 station continued to operate without damage while its surroundings were flooded by melt lake waters in 1996 and 1997.

\section{Aerial reconnaissance}

Hughes 500 helicopter aerial-reconnaissance flights were conducted on 12-15 August 2005 from the Greenpeace Motorized Yacht Arctic Sunrise, anchored in de Quervain harbor $\left(69.7612^{\circ} \mathrm{N}, 50.3748^{\circ} \mathrm{W}\right)$ near Eqip sermia. Helicopter GPS measurements of lake A's elliptical major and minor axes suggest a lake area of $1.3 \mathrm{~km}^{2}$. The center of lake $\mathrm{A}$ is $8.4 \mathrm{~km}$ from the $\mathrm{ETH} / \mathrm{CU}$ 'Swiss Camp' (see Fig. 1).

\section{METHODS}

\section{MODIS resolution sharpening}

A resolution-sharpening algorithm (L. Gumley and others, http: // rapidfire.sci.gsfc.nasa.gov / faq / MODIS_True_Color. pdf) re-projects the $500 \mathrm{~m}$ band 3 and 4 data to $250 \mathrm{~m}$, relying on (band 1 at $500 \mathrm{~m}$ )/(band 1 at $250 \mathrm{~m}$ ) resolutionreflectance ratios. The band 1 result is then applied to band 3 and 4 data, resampled to the $250 \mathrm{~m}$ grid on a pixelby-pixel basis. The working assumption is that the band 3 and 4 resolution-reflectance ratios would be equivalent with that implicit in band 1 . The spectral information in sharpened $(250 \mathrm{~m})$ band 3 and 4 data is used in surface classification, but not in lake-depth determination. For the latter, only band 1, with $250 \mathrm{~m}$ native ground resolution, is used.

\section{Atmosphere correction}

The MODIS corrected reflectance algorithm (CREFL) developed by J. Descloitres at the NASA Goddard Space Flight Center removes gross atmospheric effects, such as Rayleigh scattering, from MODIS visible bands 1-7. The MODIS land surface reflectance product (MOD09) has a more complete atmospheric correction algorithm, one that includes an aerosol correction. In clear atmospheric conditions, with no heavy aerosol loading, the CREFL reflectance product is very
Table 1. Melt lake survey statistics

\begin{tabular}{lccccc}
\hline Lake & $\begin{array}{c}\text { Number of } \\
\text { observations }\end{array}$ & $\begin{array}{c}\text { Minimum } \\
\text { observed } \\
\text { depth } \\
\text { m }\end{array}$ & $\begin{array}{c}\text { Maximum } \\
\text { observed } \\
\text { depth }\end{array}$ & $\begin{array}{c}\text { Latitude of } \\
\text { maximum } \\
\text { depth } \\
\text { m }\end{array}$ & $\begin{array}{c}\text { Longitude of } \\
\text { maximum } \\
\text { depth }\end{array}$ \\
\hline A & 335 & 1.05 & 11.5 & 69.5345 & 49.1254 \\
B & 338 & 1.25 & 10.0 & 69.4891 & 49.2112 \\
\hline
\end{tabular}

similar to the MOD09 product (http://rapidfire.sci.gsfc. nasa.gov/faq/MODIS_True_Color.pdf). Yet aerosol concentration remains an unknown source of error. While no aerosol correction is included in CREFL, by parameterizing observed depth to reflectance data some aerosol effect is implicit and therefore minimized in the calibration.

\section{Cloud clearing}

MODIS band $6(1.628-1.652 \mu \mathrm{m})$ reflectance is sensitive to solid- and liquid-phase clouds. Here, surface classification is made for pixels in which band 6 reflectance is less than 0.15 . Clouds did not hamper lake classification owing to the distinctly different color between clouds and lake pixels. However, optically thin clouds with band 6 reflectance below 0.15 can bias CREFL calculations.

\section{Depth-reflectance parameterization and data geo-coordination}

A major challenge in this study was co-registering the pointbased depth measurement data with the area-based image data. A preliminary data coordination experiment involved selecting the nearest pixel to each depth measurement. This, 'nearest-neighbor' coordination of depth and reflectance data produces a depth/reflectance scatter that is reasonably approximated by a least-squares fit of the form:

$$
D=\frac{\alpha_{0}}{R+\alpha_{1}}+\alpha_{2}
$$

where $D$ is depth and $R$ is MODIS band 1 reflectance (Fig. 2). The shape of the fit represents the exponential decay in water reflectance noted by Morassutti and LeDrew (1996). The accuracy of this function is questionable owing to the lack of spatial precision in the reflectance data.

A more precise treatment of the spatial variation is obtained by exploiting spatial autocorrelation in reflectance. The lake pixel values are not spatially independent, but include a spatial trend across the lake in two dimensions from relatively high reflectance at the lake margin to relatively low reflectance near the lake center. The reflectance spatial trend surfaces on the equal-area grid were determined for each lake using LABFit software (W. Pereira da Silva and C. Pereira da Silva, http://www.labfit.net). Adequate fits were found using seven-parameter functions. The two 'independent' variables ( $x$ in north-south and $y$ in east-west directions) are the horizontal grid coordinates. The 'dependent' variable in this case is band 1 reflectance $(R)$. As such, the trend surface fit to the $7 \times 7250 \mathrm{~m}$ grid subset for lake A (Fig. 3a) is given by:

$$
\begin{aligned}
R= & \alpha_{0} \exp \left[\alpha_{1}(y-3)^{4}+\alpha_{2}(x-3)^{4}+\alpha_{3}(y-3)^{4}(x-3)^{2}\right] \\
& +\alpha_{4} x^{0.5}+\alpha_{5} y x+\alpha_{6} .
\end{aligned}
$$




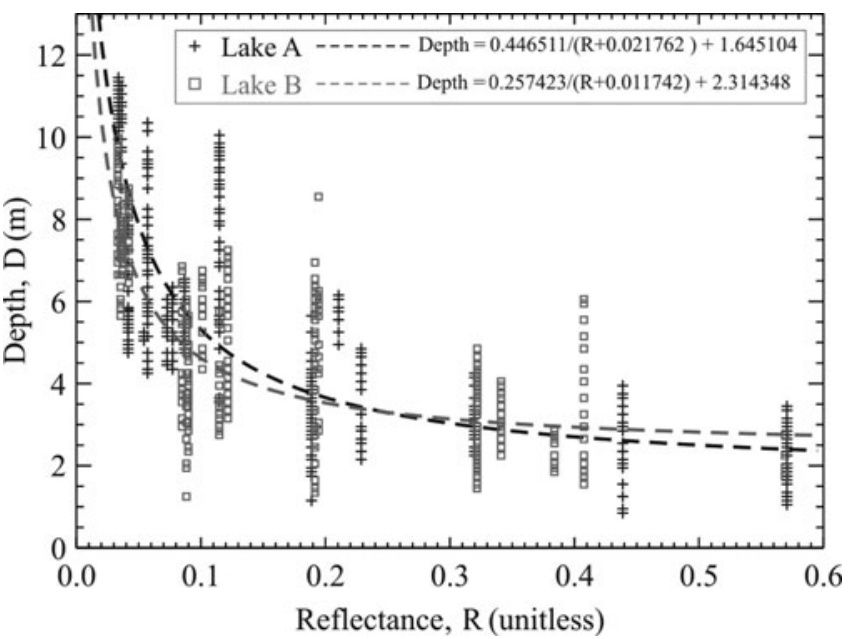

Fig. 2. Pattern of reflectance vs depth with data co-registered by the nearest-neighbor method.

Similarly, the parameterization for lake B spatial reflectance distribution on the $8 \times 9$ grid subset (Fig. $3 b$ ) is:

$$
\begin{aligned}
R= & \alpha_{0} \exp \left[\alpha_{1}(x-4)^{4}+\alpha_{2}(y-3.5)^{4}+\alpha_{3}(x-4)(y-3.5)\right. \\
& \left.+\alpha_{4}(x-y)\right]+\alpha_{5}\left(\frac{x}{2}+y\right)+\alpha_{6}
\end{aligned}
$$

The residual reflectance error $(\varepsilon)$, i.e. the standard deviation of the statistical model minus the observed reflectance, lies in the 0.04-0.07 range. The fact that the lake B error is larger is linked to lake B's shape being more asymmetric and thus harder to fit. Table 2 lists the fit parameters $\left(\alpha_{0}-\alpha_{6}\right)$, correlation coefficients and residual error. Equations (2) and (3) are then applied to compute reflectance at points corresponding to the in situ depth measurements. The results are shown after applying a technique to refine the image data geolocation.

\section{Image georeferencing}

The geolocation of the $250 \mathrm{~m}$ MODIS pixels was accomplished in two steps. The first geolocation $\left(G_{0}\right)$ is based on the NASA $1 \mathrm{~km}$ gridded viewing and illumination geometry

Table 2. Lakes A and B trend surface fit results

\begin{tabular}{lrrcc}
\hline Lake & & Parameter & $\begin{array}{c}\text { Correlation } \\
\text { coefficient }\end{array}$ & $\begin{array}{c}1 \sigma \text { residual } \\
\text { error }(\varepsilon)\end{array}$ \\
\hline $\mathrm{A}$ & $\alpha_{0}$ & $-6.2434619377 \times 10^{-1}$ & 0.985 & 0.043 \\
& $\alpha_{1}$ & $-3.8703964378 \times 10^{-2}$ & & \\
& $\alpha_{2}$ & $-1.6005826658 \times 10^{-2}$ & & \\
& $\alpha_{3}$ & $-3.9028616014 \times 10^{-2}$ & & \\
& $\alpha_{4}$ & $-6.6577235549 \times 10^{-2}$ & & \\
& $\alpha_{5}$ & $4.5594484104 \times 10^{-3}$ & & \\
& $\alpha_{6}$ & $7.1649937381 \times 10^{-1}$ & & \\
& $\alpha_{0}$ & $-6.3345026808 \times 10^{-1}$ & 0.954 & \\
& $\alpha_{1}$ & $-1.2125204354 \times 10^{-2}$ & & \\
$\alpha_{2}$ & $-5.0925672558 \times 10^{-2}$ & & \\
$\alpha_{3}$ & $8.9940397365 \times 10^{-2}$ & & \\
$\alpha_{4}$ & $-4.1721953423 \times 10^{-2}$ & & \\
$\alpha_{5}$ & $1.2263241506 \times 10^{-2}$ & & \\
$\alpha_{6}$ & $6.2199415124 \times 10^{-1}$ & & \\
& & &
\end{tabular}
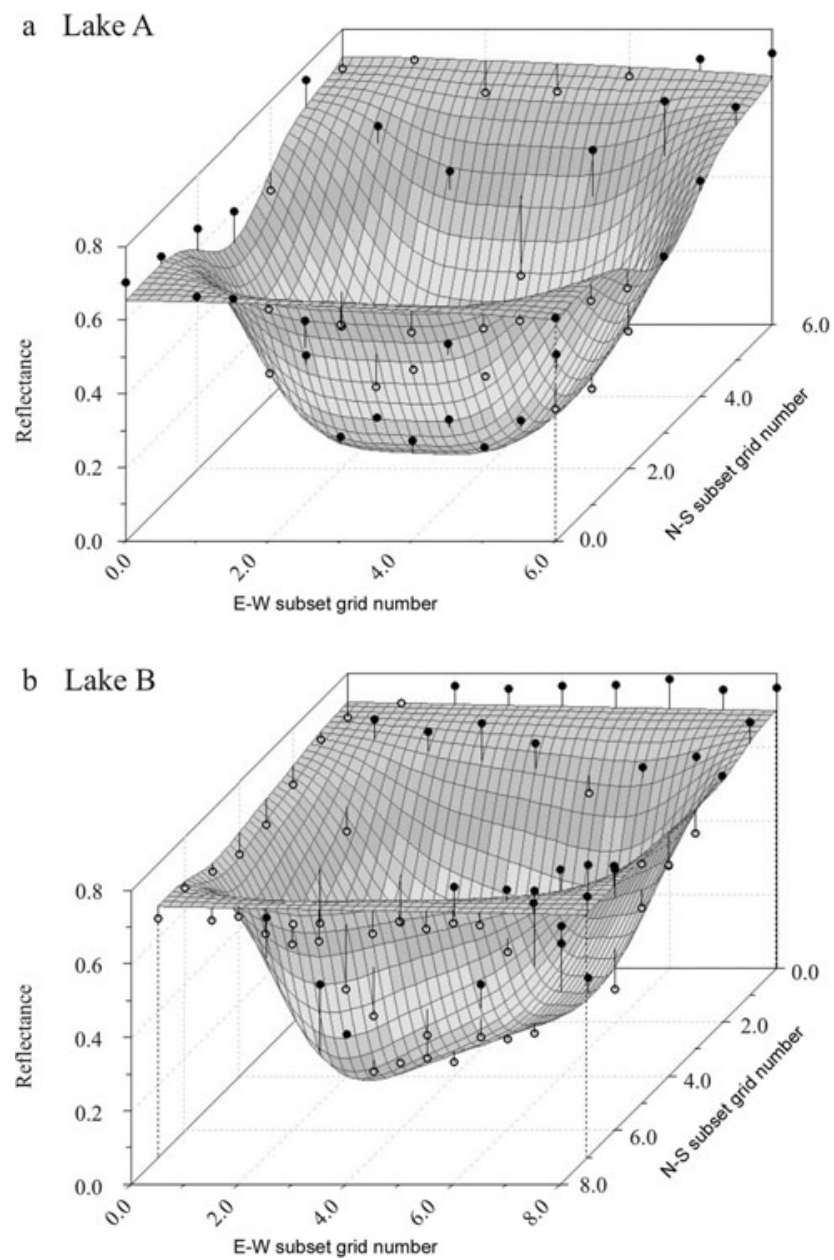

Fig. 3. Illustration of LABFit spatial trend surface fits to lake reflectance data.

product (MOD03) processed using the MODIS Swath-toGrid Toolbox (MS2GT) (Haran and others, 2001). To determine a more precise geolocation $\left(G_{1}\right)$, the equal-area grid is nudged in $0.5 \mathrm{~m}$ increments with respect to $G_{0}$, $125 \mathrm{~m}$ in all horizontal directions, while computing residual error of a least-squares-fit function of the form $D=\alpha_{0} /\left(R+\alpha_{1}\right)+\alpha_{2}$, as in Equation (1). The $x$ and $y$ geolocation offsets producing the minimum residual error are assumed to represent the most precise geolocation possible with the given data. This assumption seems valid because the offsets are roughly equivalent for the two independent lakes in the same MODIS image. Lake A and $B$ east-west offsets were 55.0 and $52.5 \mathrm{~m}$, respectively. The north-south offsets were more disparate, but still within $15 \mathrm{~m}$ of each other, that is, 30.0 and $15.0 \mathrm{~m}$, respectively. Figure 4 illustrates the MODIS data shown as a true-color image, i.e. red $=$ band 1 , green $=$ band 4 and blue $=$ band 3 pixels, with lake survey depth sample positions plotted at the two levels of georeferencing.

Figure 5 illustrates the band 1 reflectance data coregistered with depth measurements using Equations (2) and (3), including best-fit curves. The sampling seems adequate in the range $3 \mathrm{~m}<D<10 \mathrm{~m}$. For depths less than $3 \mathrm{~m}$, the sparsity of observations suggests a greater depth uncertainty. As the depth approaches zero, the bareice MODIS band 1 reflectance is observed to be $0.6 \pm 0.1$. One would thus expect the function to intercept the depth 


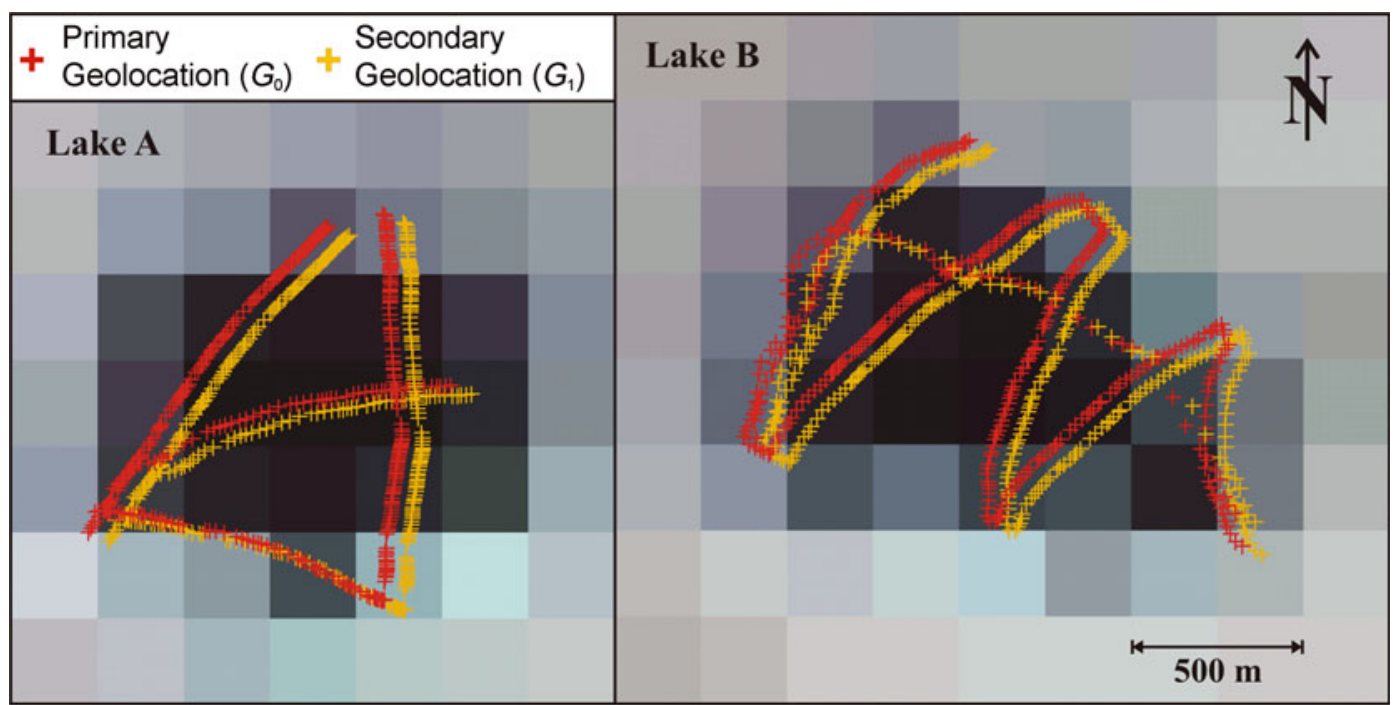

Fig. 4. Survey paths over lakes A and B with two levels of image georeferencing.

axis at $R \approx 0.6$. Rather than forcing the function in this regard, surface classification discussed in the next subsection is taken to dictate whether or not the surface is flooded.

It is noteworthy that, in the deep limit, there may be a threshold beyond which the lake no longer has reflection depletion (Morassutti and LeDrew, 1996), suggesting that depth-reflectance parameterization may underestimate maximum lake depths.

Lake detritus, that is, aolian terrestrial and extraterrestrial dust (cryoconite, e.g. Gerdel and Drouet, 1960), is dark in color and is observed to collect at the base of some lakes. Aerial-reconnaissance flight inspection of several other lakes in the northern Jakobshavn ablation region suggests detritusladen lakes are few. These lakes are the lowest-elevation lakes and are relatively small in area, that is $<1 \mathrm{~km}^{2}$. Thus, cryoconite does not seem to pose a major obstacle in accurately sounding the relatively large lakes. Since cryoconite is a relatively low-reflectance material, it would cause depth overestimation if it was of significant abundance in other, non-surveyed, lakes.

The similarity of the fit functions (Fig. 5) suggests a generalized function. That is, a fit to the scatter from lake $A$ and $B$ data taken together is useful for sounding un-surveyed lakes. Fit parameters are listed in Table 3. Note that secondary geolocation $\left(G_{1}\right)$ yields a considerable reduction in the least-squares-model error compared to the primary MOD03 geolocation $\left(G_{0}\right)$. The combined $\mathrm{A}+\mathrm{B}$ function is used to sound all image pixels classified as flooded (see Fig. 1).

\section{Image classification}

Image pixels that represent flooded areas are classified using image reflectance data. Firstly, non-flooded areas have reflectance in the $0.5-0.8$ range. At the low end of that reflectance interval is bare ice or dust/cryoconite-covered bare ice, as observed in August 2005 reconnaissance flights. The high end of the non-flooded reflectance scale represents snow-covered ice, which has melted, is melting or is in a refrozen state. Reflectance over the non-flooded areas in MODIS bands 1, 4 and 3 varies more uniformly (Fig. 6a), corresponding with the gray surface color. More precisely, a mean band-3/band- 1 ratio, that is, blue/red (B/R), of
$1.03 \pm 0.02$ is evident in the non-flooded area between lakes $\mathrm{A}$ and $\mathrm{B}$.

Reflectance over flooded areas surveyed drops to the minima listed in Table 4. Red reflectance is more reduced by the presence of lake water (Fig. 6a) than blue or green. Thus red reflectance is the most sensitive to water depth of the three bands. The relatively high blue reflectance, compared to red and green, is, of course, what gives the lakes their striking blue color. Over flooded areas, the blue/red ratio increases toward the lake centers, where water is deepest (Fig. 6b).

Band ratios that correspond to flooded areas can thus be expressed using a threshold, (blue/red) $)_{\mathrm{T}}$ in the 1.05-1.25 range, as determined experimentally, and with knowledge of the areas of lakes A and B. However, (blue/red) $)_{\mathrm{T}}$ does not consider differing concentrations of ice impurities, requiring more conservative (higher) $\left(\right.$ blue/red $_{\mathrm{T}}$ ) values to be chosen in some cases. Also, because there is some overlap in reflectance in the low range for non-flooded areas and the highreflectance range for flooded waters, that is, $0.5<R<0.7$, a red reflectance threshold, $(\mathrm{red})_{\mathrm{T}}$, in the 0.5-0.6 range was

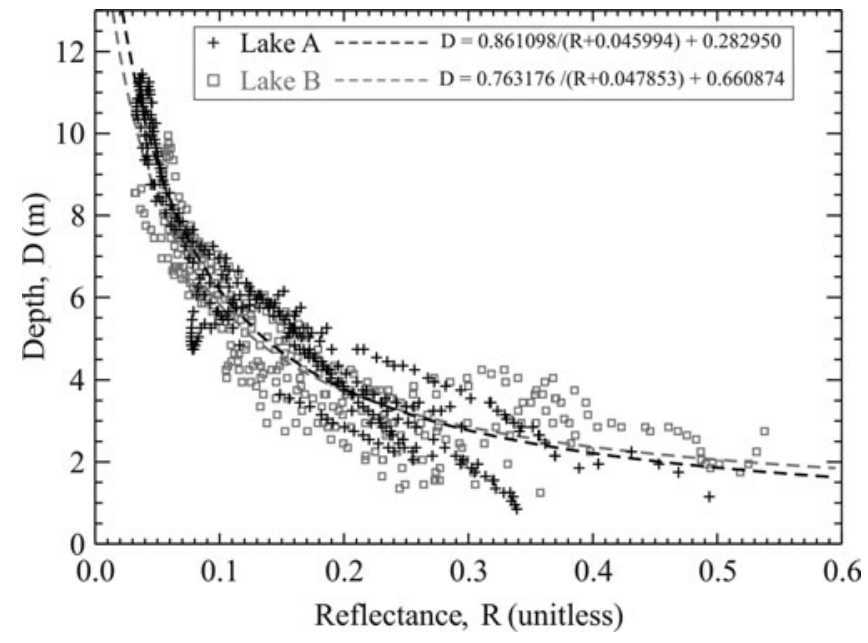

Fig. 5. Lake A and B MODIS band 1 reflectance vs depth with bestfit functions. 


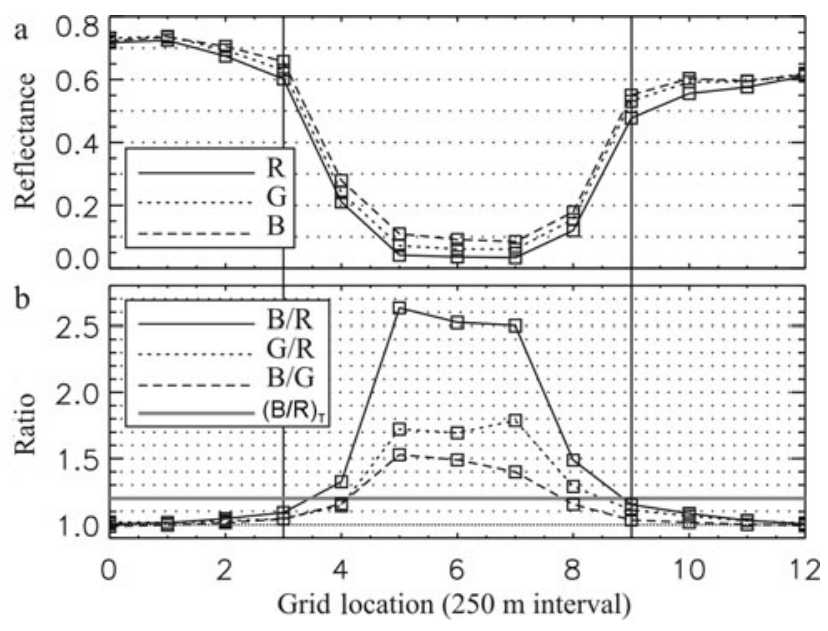

Fig. 6. Lake A transects: (a) reflectance and (b) reflectance ratios. Red, blue, green are indicated by $\mathrm{R}, \mathrm{B}, \mathrm{G}$, respectively, and $(\mathrm{B} / \mathrm{R})_{\mathrm{T}}$ is the blue/red reflectance threshold.

chosen on a lake-by-lake basis to avoid obvious misclassification. Once the classification is made, it is straightforward to compute lake area $(A)$, with $250 \mathrm{~m} \times 250 \mathrm{~m}$ pixels equalling $0.0625 \mathrm{~km}^{2}$. Lake depths $(D)$ and volume $(V)$ are calculated by applying a depth-reflectance function to classified pixels. By comparing images over time, statistics of lake-dimension changes are gathered. In addition, the maximum lake depth $\left(D_{\max }\right)$ and its location can be determined at $250 \mathrm{~m}$ horizontal precision.

\section{Lake-outburst event detection}

A geographic region containing a high concentration of lakes, i.e. $67.55-69.95^{\circ} \mathrm{N}, 47.40-51.65^{\circ} \mathrm{W}$, was chosen to search for abrupt lake-drainage events. We refer to this as 'region 1'; the extent is illustrated in Figure 1. Time-spans of 1-12 days were considered in the search for lake-outburst events. Outburst events were identified manually using sequential cloud-free images for the 6 year period covered by 2000-05 MODIS imagery. The lake center grid coordinates were used to identify lakes which occurred year after year and the lakes were assigned ID letters. For instance, lake X4 refers to lake X in the year 2004. Lakedimension changes (area, volume and maximum depth) were calculated for each lake outburst individually.

A larger geographic region, 'region $0^{\prime}$ (see Fig. 1), between $69.87,65.76^{\circ} \mathrm{N}$ and $47.28,51.55^{\circ} \mathrm{W}$ is used to compute regional statistics of total multi-lake volume and fractional areal coverage of the zone of melting by lakes. The zone of melting is approximated to that ice area where MODIS band 1 reflectance is below 0.7.

\section{RESULTS AND DISCUSSION}

\section{Lake dimensions}

The maximum area $(A)$ of a single lake in 2000-05 appears to be $8.9 \mathrm{~km}^{2}$ for lake $\mathrm{Q}\left(68.6263^{\circ} \mathrm{N}, 49.0055^{\circ} \mathrm{W}\right)$ on day 199 (17 July) 2004. A $16.9 \mathrm{~km}^{2}$ lake resulted from the merging of lakes $F$ and $G$ through a channel on day 193 (12 July) 2003. The fractional lake coverage of the region 0 zone of melting reached a maximum $2.7 \%$ on day 177 (26 June) 2005. Comparable fractional coverages are observed in other years.

The maximum depth $\left(D_{\max }\right)$ appeared to be $12.2 \mathrm{~m}$, for lake $\mathrm{Q}$ on day 188 (7 July) 2002. It seems either that the lake reflectance cannot decrease below a value of 0.027 in MODIS band 1, causing the extinction-depth relationship to lose sensitivity beyond some depth, or that lakes do not grow deeper than $12 \mathrm{~m}$ on average over areas greater than $250 \mathrm{~m} \times 250 \mathrm{~m}$ before top-over or outburst occurs.

The volume $(V)$ of individual lakes peaks in the $10^{6}-$ $10^{8} \mathrm{~m}^{3}$ range. Lake $\mathrm{Q}$ yielded the maximum estimated volume of any single lake, that is $53 \times 10^{6} \mathrm{~m}^{3}$ on day 199 (17 July) 2004. The F-G lake system registered a volume of $98.3 \times 10^{6} \mathrm{~m}^{3}$ on day 193 (12 July) 2003. Over the southwest Greenland ablation zone (region 0), lake area reached a maximum of $332 \mathrm{~km}^{2}$ with a combined water volume of $1.284 \mathrm{~km}^{3}$ on day 175 (24 June) 2003. Comparable regional volumes are observed in other years, such as $1.157 \mathrm{~km}^{3}$ on day 201 (20 July) 2005 when lake area was $293 \mathrm{~km}^{2}$.

The maximum area, volume and depth does not always occur on the same day. Nonetheless, expected patterns of positive correlation between area and volume, volume and maximum depth, and area and maximum depth are evident from the 2000-05 imagery (Tables 5 and 6). The patterns of scatter between area, volume and maximum depth (not shown) suggest two classes of lake shape, i.e. narrow and deep or wide and shallow, and seem to relate to surface topography expressions of the ice-sheet bed. While lake bathymetry varies with surface topography, it is interesting to consider that given increased solar energy absorption, the lake position is self-reinforcing, as the albedo feedback leads to larger surface ablation than for surrounding nonflooded ice.

Table 5 lists dimensional statistics for selected relatively large melt lakes for the 2005 melt season, including results for lakes A and B that have in situ surveys. As maximum area, volume and depth results do not always occur on the same day, up to three dates are listed for each lake.

Table 3. Depth-reflectance parameterization results

\begin{tabular}{|c|c|c|c|c|c|}
\hline Lake & Data coordination & $\alpha_{0}$ & $\alpha_{1}$ & $\alpha_{2}$ & $1 \sigma$ error \\
\hline \multirow[t]{3}{*}{ A } & Nearest neighbor & 0.446511 & 0.021762 & 1.645104 & 1.69 \\
\hline & Spatial trend surface $\left(G_{0}\right)$ & 0.700375 & 0.032765 & 0.633355 & 1.09 \\
\hline & Spatial trend surface $\left(G_{1}\right)$ & 0.861098 & 0.045994 & 0.282950 & 0.80 \\
\hline \multirow[t]{2}{*}{ B } & Nearest neighbor & 0.257423 & 0.011742 & 2.314348 & 1.37 \\
\hline & Spatial trend surface $\left(G_{0}\right)$ & 0.841613 & 0.062976 & 0.615499 & 1.05 \\
\hline$A+B$ & Spatial trend surface $\left(G_{1}\right)$ & 0.716738 & 0.036304 & 0.701691 & 0.86 \\
\hline
\end{tabular}


Table 4. MODIS $250 \mathrm{~m}$ grid minimum reflectance values for selected melt lakes

\begin{tabular}{lccccc}
\hline Lake & Band 1 (R) & Band 4 (G) & Band 3 (B) & $\begin{array}{c}\text { Latitude } \\
{ }^{\circ} \mathrm{N}\end{array}$ & $\begin{array}{c}\text { Longitude } \\
{ }^{\circ} \mathrm{W}\end{array}$ \\
\hline $\mathrm{A}$ & 0.034 & 0.061 & 0.085 & 69.5343 & 49.1233 \\
$\mathrm{~B}$ & 0.033 & 0.059 & 0.079 & 69.4887 & 49.2118 \\
$\mathrm{C}$ & 0.027 & 0.052 & 0.091 & 69.2986 & 48.9269 \\
$\mathrm{D}$ & 0.027 & 0.051 & 0.085 & 68.9108 & 48.9814
\end{tabular}

\section{Lake-outburst events}

In MODIS imagery, numerous melt lakes are observed that decrease in area completely in as little as 1 day. The recurring loss of a lake in the vicinity of the JAR1 AWS site was captured in hourly in situ acoustic-ranging sensor data. Roughly constant filling-rate episodes at JAR1 were terminated by comparatively rapid drainage events lasting 10 hours in 1996 and 8 hours in 1997.

Lake-dimension changes associated with selected lakeoutburst events detected by remote sensing are listed in Table 6 . Of the lake-outburst events detected in region 1 in 2000-05, the earliest was on day 168 (17 June) 2005. The latest lake outburst detected was on day 221 (9 August) 2005. Lake outbursts appear to migrate inland throughout the melt season. The average outburst date is day 191 (10 July). The average lake volume change is $-15.7 \times 10^{6} \mathrm{~m}^{3}$, with an average of more than eight events per year. The actual number of lake outbursts is very likely greater, with some relatively small events missed due to spatial resolution or during visual inspection of imagery. The largest outburst event found is that of the two large interconnected lakes $F$ and $\mathrm{G}$, forming a $98.3 \times 10^{6} \mathrm{~m}^{3}$ reservoir draining some time between days 193 and 196 (12-15 July) 2003. The reflectance changes imply a $97.4 \times 10^{6} \mathrm{~m}^{3}$ water discharge, corresponding to a constant drainage rate of $16.2 \times 10^{6} \mathrm{~m}^{3} \mathrm{~d}^{-1}$, though the drainage rate peaks in time. In another lakeoutburst case, lake G on days 188-189 (7-8 July) 2002, i.e.
Table 5. Melt lake depth and volume statistics for selected lakes in 2005

\begin{tabular}{|c|c|c|c|c|c|c|}
\hline \multirow[t]{2}{*}{ Lake } & \multirow[t]{2}{*}{ Day } & $A$ & $V$ & \multirow[t]{2}{*}{$D_{\max }$} & \multirow{2}{*}{$\begin{array}{c}D_{\max } \\
\text { latitude } \\
{ }^{\circ} \mathrm{N}\end{array}$} & \multirow{2}{*}{$\begin{array}{c}D_{\max } \\
\text { longitude } \\
{ }^{\circ} \mathrm{W}\end{array}$} \\
\hline & & $\mathrm{km}^{2}$ & $10^{6} \mathrm{~m}^{3}$ & & & \\
\hline \multirow[t]{3}{*}{ A } & 220 & 1.8 & 5.4 & 5.1 & 69.5341 & 49.1366 \\
\hline & 228 & 1.3 & 7.1 & 10.9 & 69.5343 & 49.1233 \\
\hline & 221 & 1.7 & 7.9 & 10.1 & 69.5342 & 49.1299 \\
\hline \multirow[t]{2}{*}{$\mathrm{B}^{*}$} & 209 & 2.2 & 8.3 & 8.0 & 69.4910 & 49.2187 \\
\hline & 228 & 1.5 & 7.8 & 11.0 & 69.4887 & 49.2118 \\
\hline \multirow[t]{3}{*}{$\mathrm{C}$} & 204 & 4.4 & 14.2 & 4.5 & 69.3008 & 48.9403 \\
\hline & 228 & 2.6 & 20.2 & 12.0 & 69.2986 & 48.9269 \\
\hline & 219 & 3.3 & 24.3 & 11.5 & 69.2987 & 48.9203 \\
\hline \multirow[t]{2}{*}{$\mathrm{D}^{*}$} & 203 & 2.2 & 6.7 & 5.3 & 68.9155 & 48.9753 \\
\hline & 228 & 1.8 & 10.3 & 12.1 & 68.9108 & 48.9814 \\
\hline $\mathrm{E}^{*}$ & 209 & 6.8 & 32.9 & 10.8 & 68.9084 & 48.5667 \\
\hline $\mathrm{F}^{*}$ & 203 & 6.5 & 21.7 & 6.2 & 68.6769 & 48.6581 \\
\hline \multirow[t]{2}{*}{$\mathrm{G}^{*}$} & 203 & 8.5 & 21.7 & 4.8 & 68.6751 & 48.6003 \\
\hline & 201 & 4.3 & 11.9 & 4.9 & 68.6638 & 48.5675 \\
\hline
\end{tabular}

*Some equivalence for date of area, volume and/or maximum depth.

in the G2 event, a discharge of $31.5 \times 10^{6} \mathrm{~m}^{3}$ occurred in 24 hours or less. Table 6 lists some of the largest (of 50) drainage events identified in the 2000-05 imagery. The 2003 imagery yielded the most drainage events. However, in other years, such as 2004, relatively cloudy conditions may have obscured drainage events. Lakes F, G, O, T, U, V, W and X exhibited outbursts in more than one year (Table 6). These recurrent drainage events do not necessarily have consistent drainage time intervals, as clouds occasionally obscure precise determination of drainage time. The surface morphological characteristics of these lakes should be further investigated to examine whether these are top-over or bottom-drainage events.

Depth changes indicate lake surface height changes of $-6.2 \mathrm{~m}$ in as little as 1 day (Table 6). Blue/red and red thresholds, $B / R_{T}$ and $R_{T}$, respectively, are listed to indicate

Table 6. West Greenland melt lake dimension statistics for selected outburst events, sorted by discharge volume

\begin{tabular}{|c|c|c|c|c|c|c|c|c|c|c|c|c|c|}
\hline Lake & Year & Day of year & $\begin{array}{c}\Delta t \\
\text { days }\end{array}$ & $\begin{array}{c}A \\
\mathrm{~km}^{2}\end{array}$ & $\begin{array}{l}\Delta A \\
\mathrm{~km}^{2}\end{array}$ & $\begin{array}{c}V \\
10^{6} \mathrm{~m}^{3}\end{array}$ & $\begin{array}{c}\Delta V \\
10^{6} \mathrm{~m}^{3}\end{array}$ & $\begin{array}{c}D_{\max } \\
\mathrm{m}\end{array}$ & $\begin{array}{c}\Delta D_{\max } \\
\mathrm{m}\end{array}$ & $\begin{array}{c}D_{\max } \text { latitude } \\
{ }^{\circ} \mathrm{N}\end{array}$ & $\begin{array}{c}D_{\max } \text { longitude } \\
{ }^{\circ} \mathrm{W}\end{array}$ & $B / R_{\mathrm{T}}$ & $R_{\mathrm{T}}$ \\
\hline $\mathrm{F}-\mathrm{G}$ & 2003 & 193 & 6 & 16.9 & -16.5 & 98.3 & -97.4 & 10.9 & -7.8 & 68.6779 & 48.5621 & 1.25 & 0.50 \\
\hline G2 & 2002 & 188 & 1 & 6.3 & -2.2 & 42.7 & -31.5 & 11.1 & -6.2 & 68.6802 & 48.5623 & 1.25 & 0.50 \\
\hline G1 & 2001 & 196 & 9 & 5.8 & -4.1 & 26.8 & -23.3 & 9.2 & -6.4 & 68.6779 & 48.5621 & 1.10 & 0.60 \\
\hline W5 & 2005 & 209 & 12 & 5.8 & -5.2 & 21.9 & -20.6 & 9.5 & -6.3 & 68.4282 & 48.6259 & 1.15 & 0.60 \\
\hline V4 & 2004 & 178 & 6 & 4.8 & -4.6 & 23.0 & -22.7 & 10.3 & -8.5 & 68.2358 & 48.9686 & 1.10 & 0.60 \\
\hline V2 & 2002 & 182 & 6 & 4.6 & -3.6 & 26.4 & -23.7 & 9.1 & -4.8 & 68.2358 & 48.9686 & 1.15 & 0.50 \\
\hline $\mathrm{O} 4$ & 2004 & 199 & 3 & 4.6 & -4.0 & 21.9 & -20.7 & 9.1 & -6.9 & 68.4374 & 48.8419 & 1.15 & 0.50 \\
\hline X5 & 2005 & 200 & 1 & 3.9 & -1.4 & 12.7 & -6.7 & 8.7 & -4.6 & 68.1645 & 49.2496 & 1.10 & 0.60 \\
\hline $\mathrm{F} 2$ & 2002 & 188 & 1 & 3.7 & -2.5 & 16.0 & -13.3 & 8.6 & -6.0 & 68.6835 & 48.6907 & 1.25 & 0.50 \\
\hline F1 & 2001 & 196 & 9 & 3.5 & -3.0 & 11.0 & -10.0 & 6.1 & -3.7 & 68.6836 & 48.6843 & 1.10 & 0.60 \\
\hline X4 & 2004 & 178 & 6 & 2.9 & -2.2 & 14.9 & -13.2 & 10.0 & -5.3 & 68.1646 & 49.2434 & 1.18 & 0.50 \\
\hline O5 & 2005 & 209 & 12 & 2.8 & -2.7 & 10.0 & -9.8 & 8.8 & -6.5 & 68.4373 & 48.8482 & 1.09 & 0.40 \\
\hline W1 & 2001 & 206 & 1 & 2.4 & -0.4 & 11.0 & -4.8 & 9.1 & -2.7 & 68.4260 & 48.6131 & 1.10 & 0.60 \\
\hline U2 & 2002 & 182 & 6 & 2.1 & -2.1 & 8.7 & -8.7 & 10.0 & -10.0 & 69.0220 & 49.0377 & 1.15 & 0.50 \\
\hline U1 & 2001 & 192 & 3 & 1.8 & -0.9 & 5.5 & -3.7 & 7.2 & -5.1 & 69.0197 & 49.0375 & 1.10 & 0.60 \\
\hline T1 & 2001 & 196 & 9 & 1.4 & -0.8 & 4.1 & -2.9 & 7.4 & -4.8 & 68.9939 & 49.2170 & 1.10 & 0.60 \\
\hline
\end{tabular}


that surrounding surface reflectance properties were variable from lake to lake, and were refined, but can affect dimensional retrieval accuracy to a second order.

\section{Considerations of lake-outburst flooding mechanisms and ice flow}

The implications of lake-outburst events are of critical interest for the better understanding of ice-sheet flow dynamics and the hydraulic response of the ice sheet to climate warming. Parizek and Alley (2004) parameterized flow enhancement related to surface meltwater production in global-warming scenarios using information from Zwally and others (2002), but did not directly consider the pulses of water provided by lake outbursts. Engelhardt (1978) and Bindschadler (1983) reported basal water-pressure observations that are linked to enhanced basal sliding in cases of summer peak meltwater production or after heavy rainfall. Vieli and others (2004) confirmed this link on Hansbreen, Svalbard, stating: 'The close correlation between water pressure recorded in a moulin and the observed surface velocities suggests that the speed-ups are caused by a strong increase of basal water pressure which leads to enhanced basal sliding.' The strong increase in basal water pressure can be provided by melt lake outburst. A moulin kept full of water would produce a greater basal pressure than that exerted by the same overburden of ice, no matter what the ice-sheet thickness, given the higher density of water than ice.

The $8000 \mathrm{~m}^{3}$ of water needed to fill a moulin with $10 \mathrm{~m}^{2}$ effective cross-sectional area at an ice thickness of $800 \mathrm{~m}$ is less than $0.1 \%$ of the available water volume in the case of an average lake-outburst event (Table 6). Thus, basal pressurization could be maintained over a period of hours to days.

It is worth considering over what subglacial area this water would spread. If subglacial void thickness were effectively $1 \mathrm{~m}$, the water volume from the large FG2003 outburst could spread over an area of $97 \mathrm{~km}^{2}$. If the subglacial cavities were constrained laterally, as in the case of a subglacial valley channel, it seems more likely that basal pressure could be maintained.

\section{CONCLUSIONS}

In situ depth and remotely sensed reflectance data can be combined to estimate supraglacial melt lake depth and volume, once the lake surface area has been derived from image classification. Lake classification is achieved using the MODIS band 1-3 reflectance ratio; a lake has $1.05<$ $\mathrm{B} / \mathrm{R}_{\mathrm{T}}<1.25$ and a band 1 reflectance less than 0.4-0.6. A lake-depth parameterization is proposed, based on the exponential decay of lake reflectance with water depth. The empirical fit is made between satellite-observed reflectance and in situ observed depth. The implicit relationship between depth and reflectance was equivalent at two independent lakes where depth surveys were made. Thus, a generalized depth-reflectance parameterization seems applicable to other lakes, at least to those lakes with no significant concentrations of dark-colored cryoconite dust.

Uncertainty in the remotely sensed lake dimensions stems from errors in co-registration of in situ point-based depth data with area-based image data, variable detritus concentration in some lakes, limited MODIS spatial resolution $(250 \mathrm{~m})$ and mixed pixels along lake margins. Precise in situ depth data were georeferenced with image data in an iterative procedure to refine geolocation to sub-pixel precision.
Cloud-free images spanning 6 years (2000-05) yield information on maximum lake depth $(12.2 \mathrm{~m})$, maximum single-lake area $\left(8.9 \mathrm{~km}^{2}\right)$ and maximum single-lake volume $\left(53 \times 10^{6} \mathrm{~m}^{3}\right)$. Many lakes recur year after year in the same topographic basin. The peak combined volume for all lakes on the western slope of the ice sheet between 69.87 and $65.76^{\circ} \mathrm{N}$ was $1.284 \mathrm{~km}^{3}$ on day 175 (24 June) 2003, with similar maxima in other years.

Cases of abrupt drainage, up to $31.5 \times 10^{6} \mathrm{~m}^{3} \mathrm{~d}^{-1}$, provide englacial and basal water fluxes that seem to be important in the enhancement of hydraulic basal sliding. Based on observations at the surface of moulin diameters, on the order of $10 \mathrm{~m}^{2}$, a moulin can contain only a small fraction of the lake-outburst water volume. Thus, a pressurized basal environment can be maintained during outbursts lasting hours to days, given the conditions necessary to hydraulically lubricate and even uplift the ice-sheet surface, at least locally. Melt lake outburst waters thus have the capacity to play a significant role in ice-sheet response to surface climate via seasonal meltwater production.

\section{ACKNOWLEDGEMENTS}

This study was supported by The US National Science Foundation Office of Polar Programs grant ARC-0531306 and The Ohio State University Geography Department Lawrence Brown Faculty Fellowship. Logistical support for fieldwork was provided by Greenpeace. We thank J. Hoelscher for boating expertise. G. Bryzgis gathered many of the raw MODIS data. J. Bamber, W. Wang and an anonymous reviewer are thanked for their input. This is Byrd Polar Research Center contribution No. 1340.

\section{REFERENCES}

Abdalati, W. and K. Steffen. 2001. Greenland ice sheet melt extent: 1979-1999. J. Geophys. Res., 106(D24), 33,983-33,988.

Alley, R.B., T.K. Dupont, B.R. Parizek and S. Anandakrishnan. 2005. Access of surface meltwater to beds of subfreezing glaciers: preliminary insights. Ann. Glaciol., 40, 8-14.

Bindschadler, R. 1983. The importance of pressurized subglacial water in separation and sliding at the glacier bed. J. Glaciol., 29(101), 3-19.

Boon, S. and M. Sharp. 2003. The role of hydrologically-driven ice fracture in drainage system evolution on an Arctic glacier. Geophys. Res. Lett., 30(18), 1916. (10.1029/2003GL018034.)

Box, J.E. and 8 others. 2006. Greenland ice sheet surface mass balance variability (1988-2004) from calibrated polar MM5 output. J. Climate, 19(12), 2783-2800.

Bryzgis, G. and J.E. Box. 2005. West Greenland ice sheet melt lake observations and modeling. EOS Trans. AGU, 86(52), C41A-07.

Curry, J.A., J.L. Schramm and E.E. Ebert. 1995. Sea ice-albedo climate feedback mechanism. J. Climate, 8(2), 240-247.

Echelmeyer, K., T.S. Clarke and W.D. Harrison. 1991. Surficial glaciology of Jakobshavns Isbræ, West Greenland: Part I. Surface morphology. J. Glaciol., 37(127), 368-382.

Engelhardt, H. 1978. Water in glaciers: observations and theory of the behaviour of water levels in boreholes. Z. Gletscherkd. Glazialgeol., 14(1), 35-60.

Gerdel, R.W. and F. Drouet. 1960. The cryoconite of the Thule area, Greenland. Trans. Am. Microsc. Soc., 79(3), 256-272.

Haran, T.M., S.J.S. Khalsa, K. Knowles and L.E. Gumley. 2001. The MODIS Swath-to-Grid Toolbox. EOS Trans. AGU, 82(20), U21A-22. 
Joughin, I., S. Tulaczyk, M. Fahnestock and R. Kwok. 1996. A minisurge on the Ryder Glacier, Greenland, observed by satellite radar interferometry. Science, 274(5285), 228-230.

Liestøl, O., K. Repp and B. Wold. 1980. Supra-glacial lakes in Spitsbergen. Nor. Geogr. Tidsskr., 34(2), 89-92.

Lüthje, M., L.T. Pedersen, N. Reeh and W. Greuell. 2006. Modelling the evolution of supraglacial lakes on the West Greenland icesheet margin. J. Glaciol., 52(179), 608-618.

Morassutti, M.P. and E.F. LeDrew. 1996. Albedo and depth of melt ponds on sea ice. Int. J. Climatol., 16(7), 817-838.

Parizek, B.R. and R.B. Alley. 2004. Implications of increased Greenland surface melt under global-warming scenarios: icesheet simulations. Quat. Sci. Rev., 23(9-10), 1013-1027.

Perovich, D.K., W.B. Tucker, III and K.A. Ligett. 2002. Aerial observations of the evolution of ice surface conditions during summer. J. Geophys. Res., 107(C10), 8048. (10.1029/ 2000JC000449.)

Rignot, E. and P. Kanagaratnam. 2006. Changes in the velocity structure of the Greenland Ice Sheet. Science, 311(5673), 986-990.
Steffen, K. and J. Box. 2001. Surface climatology of the Greenland ice sheet: Greenland Climate Network 1995-1999. J. Geophys. Res., 106(D24), 33,951-33,964.

Steffen, K., J. Box and W. Abdalati. 1996. Greenland climate network: GC-Net. CRREL Spec. Rep. 96-27, 98-103.

Thomsen, H.H., L. Thorning and R.J. Braithwaite. 1988. Glacierhydrological conditions on the Inland Ice north-east of Jacobshavn/llulissat, West Greenland. Grønl. Geol. Unders. Rapp. 138.

Van der Veen, C.J. 1998. Fracture mechanics approach to penetration of surface crevasses on glaciers. Cold Reg. Sci. Technol., 27(1), 31-47.

Vieli, A., J. Jania, H. Blatter and M. Funk. 2004. Short-term velocity variations on Hansbreen, a tidewater glacier in Spitsbergen. J. Glaciol., 50(170), 389-398.

Weertman, J. 1973. Can a water-filled crevasse reach the bottom surface of a glacier? IASH Publ. 95 (Symposium at Cambridge 1969 - Hydrology of Glaciers), 139-145.

Zwally, H.J., W. Abdalati, T. Herring, K. Larson, J. Saba and K. Steffen. 2002. Surface melt-induced acceleration of Greenland ice-sheet flow. Science, 297(5579), 218-222.

MS received 2 August 2006 and accepted in revised form 19 January 2007 